\title{
Field Investigation of Earthquake Under Abnormal Conditions-A Case Study of Shiqu Earthquake with M5.6 in Sichuan Province
}

\author{
Sen Qiao ${ }^{1 *}$, Zongchao $\mathrm{Li}^{1}$, Aiwen Liu ${ }^{1}$, Xueliang Chen ${ }^{1}$, \\ Li Changlong ${ }^{1}$, Li Tiefei ${ }^{1}$, Zhang Bo ${ }^{1,2}$ \\ ${ }^{1}$ Institute of Geophysics, China Earthquake Administration, Beijing 100081, China \\ ${ }^{2}$ Hebei University of Architecture, Zhangjiakou, Hebei, 075000, China \\ ${ }^{*}$ Corresponding author. Email:qiaosen@,cea-igp.ac.cn
}

\begin{abstract}
In this paper, taking the earthquake of Ms5.6 occurred in Shiqu County, Ganzi Prefecture, Sichuan Province at 20:23 on April 1, 2020 as an example, the main measures to carry out earthquake site investigation and emergency response under abnormal conditions (epidemic situation of new coronavirus) are analyzed, and the seismicity, seismotectonic background, focal mechanism, earthquake disaster distribution characteristics and earthquake intensity distribution of Shiqu earthquake are emphatically analyzed. Based on the analysis of the main measures of earthquake site investigation and emergency response under abnormal conditions, suggestions on improving earthquake emergency response plan and revising relevant standards are put forward.
\end{abstract}

Keywords: Abnormal, Corona Virus Disease 2019, Shiqu earthquake, Filed investigation, Earthquake emergency

\section{非常态下的地震现场考察与研究}

\section{一一以四川石渠 5.6 级地震为例}

乔森 $1^{*}$ ，李宗超 ${ }^{1}$ ，刘爱文 ${ }^{1}$ ，陈学良 ${ }^{1}$ ，李昌珑 ${ }^{1}$ ，李铁飞 ${ }^{1}$ ，张波 ${ }^{1,2}$

\author{
1.中国地震局地球物理研究所, 北京 100081 \\ 2.河北建筑工程学院 土大工程学院，河北 张家口 075000 \\ *通讯作者.电子邮箱: qiaosen@cea-igp.ac.cn
}

\section{摘要}

本文以 2020 年 4 月 1 日 20 时 23 分四川省甘孜州石渠县发生 5.6 级地震为例, 分析了在非常态下（新冠病毒 疫情) 开展地震现场考察与应急响应的主要措施, 并着重分析了石渠地震的地震活动情况、地震构造背景、震 
源机制解、地震灾害分布特征及地震烈度分布情况。通过分析在非常态下 (新冠病毒疫情) 地震现场考察与应 急响应的主要措施，提出完善地震应急响应预案及修订相关标准的建议。

关键词: 非常态, 新冠肺炎, 石渠地震, 地震现场考察, 地震应急响应

\section{1. 引言}

2003 年在国内爆发了非典疫情（SARS），对中 国的经济社会发展造成了一定的冲击影响。2020 年 1 月新冠肺炎突然爆发 (图 1), 武汉紧急封城, 全国 大部分地区的民众被迫居家隔离, 疫情导致商贸餐饮、 文化娱乐、度假旅游等服务业几乎瞬间停业, 引发交 通中断、大量企业停工, 其产生的有形的经济损失和 无形的社会影响难以估量。而且, 在此次抗击疫情期 间, 国内发生多次 4.0 级-5.5 级地震。2 月 3 日 0 时 5 分在四川成都市青白江区 (北纬 30.74 度, 东经 104.46 度) 发生 5.1 级地震, 震源深度 $21 \mathrm{~km}$, 成都市 区震感特别强烈; 2 月 18 日 17 时 07 分在山东济南 长清区（北纬 36.47 度, 东经 116.64 度) 发生了 4.1 级地震, 震源深度 $10 \mathrm{~km}$, 震感较为强烈; 这两次地 震都造成了一定的社会恐慌。2 月 6 日, 四川省应急 管理厅印发了《疫情期间重特大地震应对准备重点工 作方案》 ${ }^{1]}$, 进行了较为详细的工作部署, 产生了明 显的积极作用。有幸的是疫情发生到目前为止, 在国 内没有发生可能造成人员伤亡的特大、重大破坏性地 震。如果在疫情重灾区再发生重特大破坏性地震, 急 需全社会给予大量人力和物力上的紧急救援, 很多地 方的交通被限制, 新冠肺炎还具有很高的传染性, 面 对如此复杂而严峻的形势, 我们的各级政府、地震部 门、应急管理部门及其他相关部门应该怎样及时有效 的应对, 才能做到在保证疫情不会进一步的扩散和加 重的前提下, 使受灾人员得到救助, 以最大限度地降 低非常态事件及地震灾害造成的伤害和财产损失。本 文以四川石渠 5.6 级地震为例, 分析了在新冠病毒疫 情下, 开展地震现场考察与应急响应的主要措施, 研 究了石渠地震的地震活动性、发震构造背景、震源机 制解及地震烈度分布情况, 并提出了完善地震应急 响应预案及修订相关标准的建议。

\section{2. 石渠地震基本概况}

根据中国地震台网测定，2020 年 4 月 1 日 20 时 23 分, 在四川省甘孜州石渠县 (北纬 33.04 度, 东经 98.92 度）发生 5.6 级破坏性地震（图 2）, 震 源深度 $10 \mathrm{~km}$ 。截至 2020 年 4 月 4 日 24 时 00 分共 记录到 1.0 级及以上余震 159 次。其中 $5.0 \sim 5.9$ 级 地震 0 次, $4.0 \sim 4.9$ 级地震 1 次, $3.0 \sim 3.9$ 级地震 4 次, $2.0 \sim 2.9$ 级地震 61 次, $1.0 \sim 1.9$ 级地震 93 次。 此次地震的最高烈度为VIII度 (7 度)。地震影响范 围主要涉及到四川省甘孜藏族自治州石渠县、德格 县、甘孜县; 青海省果洛藏族自治州达日县; 共计 4 个县、11 个乡镇。此次地震是发生在四川甘孜藏 族自治州的一次中强破坏性地震, 本次地震虽然没 有造成人员伤亡，但给当地人民造成一定的经济财 产损失，对当地经济社会发展造成了一定的影响。

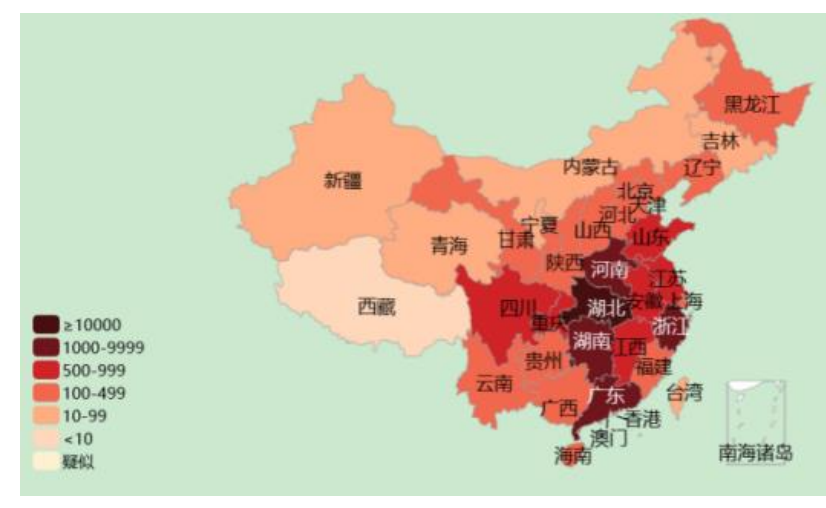

图 1 全国累计感染新冠肺炎分布图 （https://m.look.360.cn/subject/400?sign=360dh） 
四川石渠 5.6 级地 震 余震序列 分 布 图(截止2020.4.4)

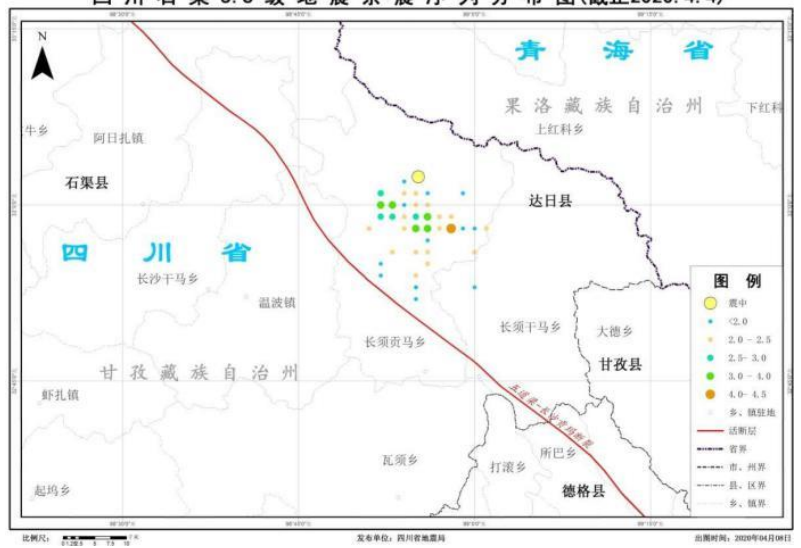

图 2 石渠地震震中分布图

在此阶段, 正处在新冠病毒疫情高传染性发生 的情况下，全国各省、市、县、乡镇、村（社区） 都处于静止隔离状态, 避免人的接触传播。而地震 发生却需要全社会的紧急救援, 需要相应的人员赴 灾区救助伤员。两个事件本身是相互影响的,如果处 置不当,就会造成地震灾害和疫情灾害的叠加。在新 冠疫情的严峻形势下, 四川省地震局组织开展了有 条不紊、科学合理的地震现场考察、震害调查、应 急处置及科学考察工作。

\section{3. 地震活动与地震构造}

\section{1 石渠 5.6 级地震的地震活动及震源机制}

石渠地震的余震分布如图 2 所示, 沿着北西条 带展布。选取四川、青海区域地震台网震中距 300 千米以内台站的宽频带波形记录，采用 CAP 方法 反演获得了石渠 5.6 级地震震源机制解（图 3)。 结果显示, 错动类型为走滑型, 最佳拟合深度为 7 千米。节面参数为, 节面 I : 走向 $125^{\circ}$, 倾角 $90^{\circ}$ ，滑动角 $-4^{\circ}$; 节面 II : 走向 215 ，倾角 $86^{\circ}$ ，滑动角 $-180^{\circ}$ 。

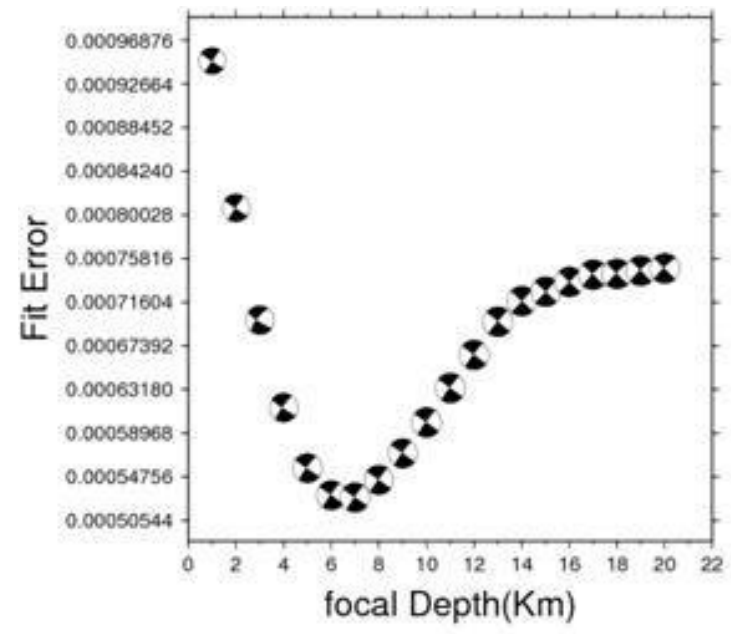

图3 震源机制解图（据四川省地震预

报中心）

\section{2 石渠地震的发震构造背景}

此次地震的震中位于巴颜喀拉块体南边界断裂 附近（图 4），块体北边界为东昆仑断裂带，南边 界为鲜水河断裂带, 而东边界则是由龙门山断裂带 及其北西侧的若干次级断裂带组成的活动构造与断 裂系统。巴颜喀拉块体的运动方向约为北东 $61^{\circ}$ ， 东部由于受到稳定的华南块体的阻挡，在这两个块 体的边界带龙门山断裂带及其附近，以挤压逆冲为 主兼具右旋走滑性质的构造变形为响应，在龙门山 以西的宽度约 200 多千米的地带产生 $3.5 \sim 6 \mathrm{~mm} / \mathrm{a}$ 的水平缩短和 $2 \sim 6 \mathrm{~mm} / \mathrm{a}$ 的剪切变形。

晚新生代以来，伴随着青藏高原持续抬升和高 原物质向东扩散的影响，高原东部地区表现出地壳 抬升、变形与缩短和块体的旋转与侧向挤出等复杂 的变形过程, 奠定了该地区的现今构造格局。而区 内 6 级以上地震特别是 7 级以上大震也丛集于这 些地球物理场畸变带上。区内主要发育北西、北西 西和近南北向的断裂构造, 特别是在甘孜一玉树断 裂、乌兰乌拉湖一玉树断裂、达日断裂和巴青一类 乌齐断裂上的近代地震具有强度大、频度高的特 点, 历史上均发生过 7 级以上强震或存在史前古地 震的地质纪录。 


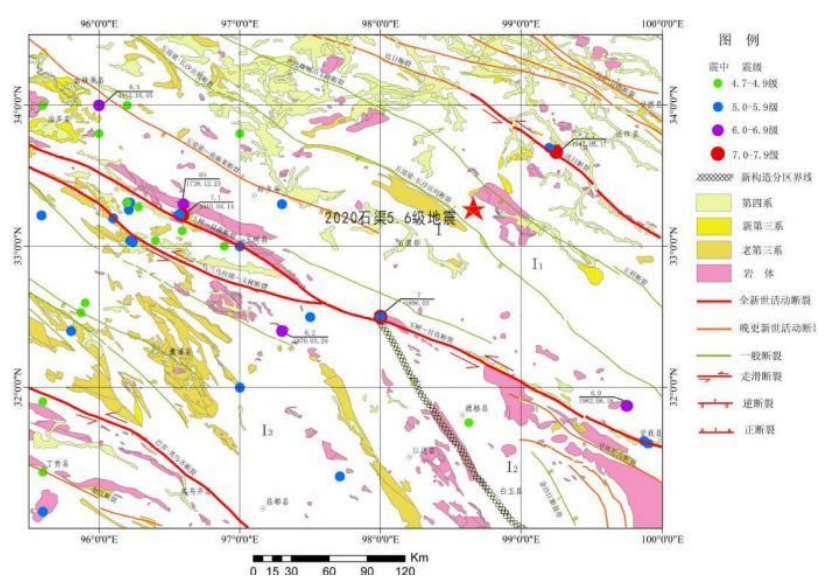

图4 地震构造分布图

此次地震附近发育有达日断裂、五道梁-长沙贡 马断裂、五道梁-曲马断裂、玉树-甘孜断裂与乌兰乌 拉湖-玉树断裂。

(1)达日断裂。该断裂线性影像清晰，断裂切割 I 级河流阶地和山前冲洪积扇, 发育有长约 $60 \mathrm{~km}$ 的地表破裂带。断裂水平平均滑动速率为 14.2 $\mathrm{mm} / \mathrm{a}$, 历史上曾发生过 1947 年 7.7 级大地震、 1949 年 6.0 级、 1961 年 5.2 级等中强地震。

(2)五道梁一长沙贡玛断裂。该断裂南东起炉霍 县侏倭乡附近, 向北西经长沙贡玛、石渠县宜牛乡 北, 逐渐并入东昆仑断裂, 长逾 $550 \mathrm{~km}$ 。该断裂在 震区一带线性特征清晰, 沿线控制着第三纪盆地沉 积, 断错水系、山脊等形成断层槽谷等地貌地形。 现场初步调查表明, 卫星影像的线性特征确实为断 层活动行迹, 从断层断错的水系和地层分析, 断裂 为左旋走滑断层, 该断层可能具备全新世活动性。

(3)五道梁一曲麻莱断裂。该断裂为晚更新世活 动断裂, 尤其北西段曲麻莱一带的晚第四纪活动形 迹明显, 称多以南段则表现不甚明显。该断裂具有 分段活动性、规模较大, 其北西段晚第四纪新活动 形迹明显, 曾发生过 1915 年 6.5 级地震; 南东段的 活动形迹虽然表现不甚明显, 但曾发生过 1977 年 5.3 级、 1986 年 4.7 级、 2003 年 4.8 级等多次中等强 度地震。
(4) 甘孜一玉树断裂与乌兰乌拉湖一玉树断裂。 甘孜一玉树断裂全长约 $500 \mathrm{~km}$, 全新世以来的平均 水平滑动速率在 7 12 mm/a 左右。其当江段晚第 四纪活动活动形迹明显, 规模大, 长度超过 350 $\mathrm{km}$, 历史上发生过多次 5 以上的中强地震。其玉树 段和乌兰乌拉湖-玉树断裂南东段交汇于巴塘盆地南 东, 地震地质活动形迹明显, 历史上发生多次中、 强地震, 其中 2010 年 7.1 级地震产生了近 $65 \mathrm{~km}$ 长 的地表破裂带; 其邓柯段地震地质活动形迹明显, 历史上发生 1896 年 7.5 级地震, 在挡托、正科乡下 拉村一带仍断续保留着 1896 年地震的地表破裂带。

\section{3 关于发震构造的确定}

在震区附近发育五道梁一长沙贡玛断裂, 从断 层的卫星影像和初步的现场地质调查发现, 该断裂 在震区附近表现为左旋走滑特征, 且线性地貌清 晰, 断层晚第四纪断错地貌发育, 初步认为该断裂 为以左旋走滑特征为主的全新世活动断裂。该断裂 在震区附近结构较为复杂, 初步的分析认为该断裂 在震中区一带表现为左旋右阶结构, 这一结构形成 挤压环境，更有利于应力集中和积累。

本次地震的震源机制解 (图 3) 显示, 本次地 震为走滑型地震, 矩心深度 $7 \mathrm{~km}$ 左右。节面走向分 别为: 节面 I: 走向 $125^{\circ}$, 倾角 $90^{\circ}$, 滑动角 $-4^{\circ}$; 节 面 II: 走向 $215^{\circ}$, 倾角 $86^{\circ}$, 滑动角 $-180^{\circ}$; 显示 该次地震为以走滑为主要特征, 与该区域的地震构 造背景相一致。余震序列分布 (图 2) 呈北西向分 布, 长约 $9 \mathrm{~km}$, 宽约 $2 \mathrm{~km}$, 反映了发震构造为断层 总体北西走向, 倾角高陡, 这与震源机制解相一 致。从震源机制解、断层活动性、结构与构造、余 震分布等特征的综合分析, 认为该次地震的发震构 造为五道梁一长沙贡马断裂。

\section{4. 震害调查及烈度分布特征}

依据《地震现场工作: 调查规范》（GB/T 18208.3-2011 )[2]、《中国地震烈度表》(GB/T 177422008） [3]，四川省地震局现场工作队对甘孜藏族自 
治州 3 个县共 11 个乡镇 34 个调查点展开了实地 调查，参考震区构造背景、震源机制解、余震序列 分布等科技支撑成果，结合强震动观测记录、青海 省相邻地区的破坏情况, 确定此次地震的地震烈度 分布图（图 5) ${ }^{[4]}$ 。最高烈度为VII度（7 度），等震 线长轴呈北西走向, 其长轴 80 千米, 短轴 54 千 米, 主要涉及到四川省甘孜藏族自治州石渠县、德 格县、甘孜县; 青海省果洛藏族自治州达日县, 共 计 4 个县。

VII度 (7 度) 区面积为 360 平方千米, 主要涉及 四川省甘孜藏族自治州石渠县的长须贡马乡、长须干 马乡 2 个乡。 VI度 (6 度) 区面积为 3140 平方千米, 主要涉及四川省甘孜藏族自治州石渠县长须贡马乡、 长须干马乡、温波镇、长沙干马乡、瓦须乡、阿日扎 镇 6 个乡镇, 徳格县的打滚乡、所巴乡、阿须镇 3 个 乡镇, 甘孜县的大德乡 1 个乡; 青海省果洛藏族自治 州达日县的上红科乡 1 个乡, 共计 11 个乡镇。

四川石渠 5.6 级地震烈度图
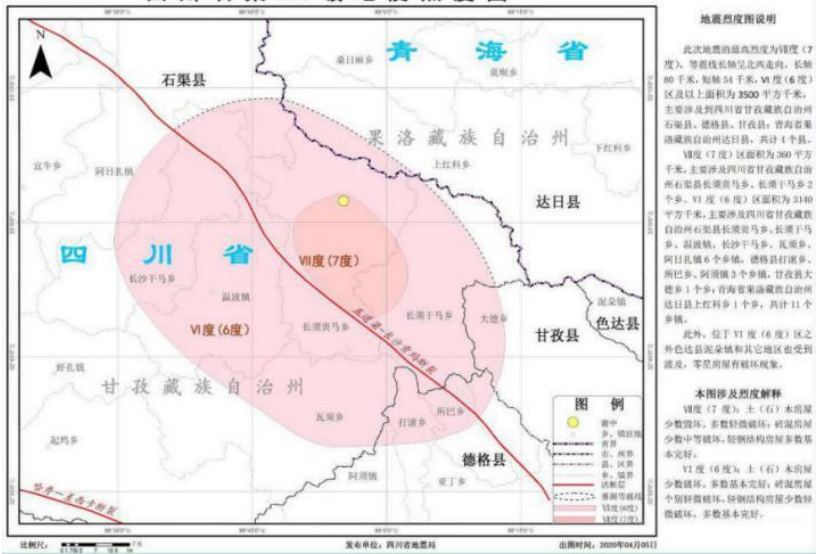

图 5 四川石渠 5.6 级地震烈度图

在地震灾区的房屋建筑结构的主要类型有, 框架 结构、专混结构、轻钢结构、以及土 (石) 木结构。 本次地震中, 轻钢结构民房的总体破坏情况较轻, 填 充墙体与柱、梁、基础等连接处普遍出现轻微裂缝, 新型复合墙体的外墙涂层局部脱落较为普遍。土(石) 木结构民房的破坏相对较重, 少数房屋墙体歪闪、局 部垮塌, 柱顶梁连接处位错, 大多数房屋的墙体出现 不同程度的裂缝。框架、砖混和轻钢结构的公用房屋
在本次地震中基本无震害, 只出现个别的墙体细微裂 缝。调查发现, 受地理环境、二次搬运成本高和建筑 施工工艺不规范等客观因素制约, 震区民房的普遍修 建质量不高, 特别是房屋的基础, 处理工艺相对简单, 加之场地条件有限, 多为III类场地, 个别区域甚至是 $\mathrm{IV}$ 类场地, 这是本次地震民用房屋震害较重的主要原 因。

根据政府有关部门资料及现场调查结果, 不同烈 度区内不同房屋结构类型破坏情况如下: VI 度 (6 度) （图 6）: 土（石）木房屋为主要房屋结构类型，少 数破坏, 多数基本完好; 砖混房屋个别轻微破坏, 多 数基本完好; 轻钢结构房屋个别轻微破坏, 大多数基 本完好；VII度（7 度）（图 7）：土（石）木房屋为 主要房屋结构类型, 多数为老旧房屋, 抗震性能较差, 少数毁坏, 多数轻微破坏; 砖混结构房屋占极少数, 多为公房，少数中等破坏，多数基本完好; 框架结构 房屋占少数, 均为轻钢结构房屋, 修建年代较新, 多 为转移安置和异地搬迁等惠民工程修建房屋, 抗震性 能较好, 少数轻微破坏, 多数基本完好。

(6a)

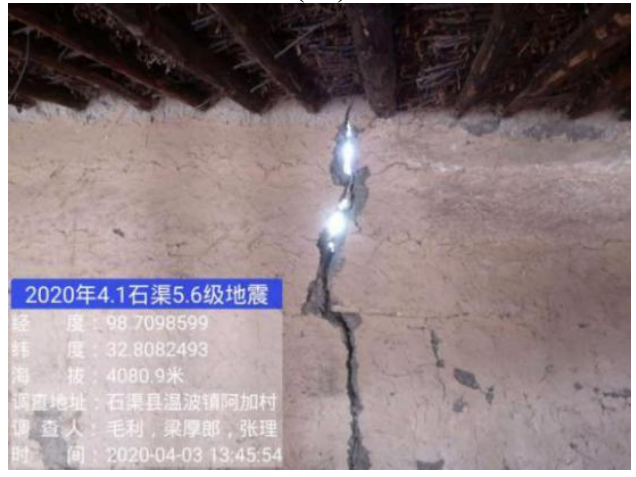

(6b)

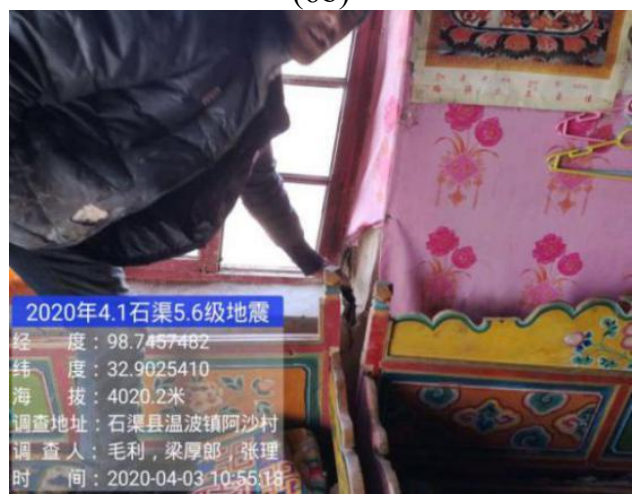




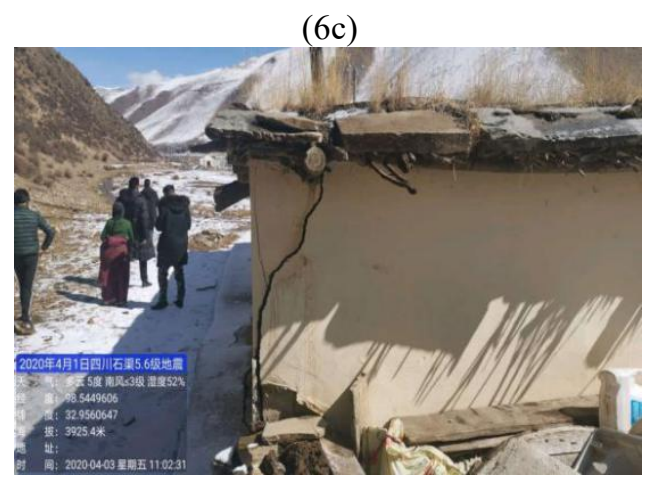

图 6 (a)温波镇阿加村土木结构房屋墙体严重开裂;

（b）温波镇阿沙村石木结构房屋沿窗角严重开裂;

（c）长沙干马乡土木结构房屋墙体贯通性裂缝（VI 度震害照片)

本次地震中生命线和行业系统的工程结构遭受 破坏程度较轻。地震造成个别道路边坡垮塌和路基沉 降, 滚石掉落阻断公路。另外部分乡镇的水井房、垃 圾池、水源地保护配套基础等设施也受到不同程度震 损。

(7a)

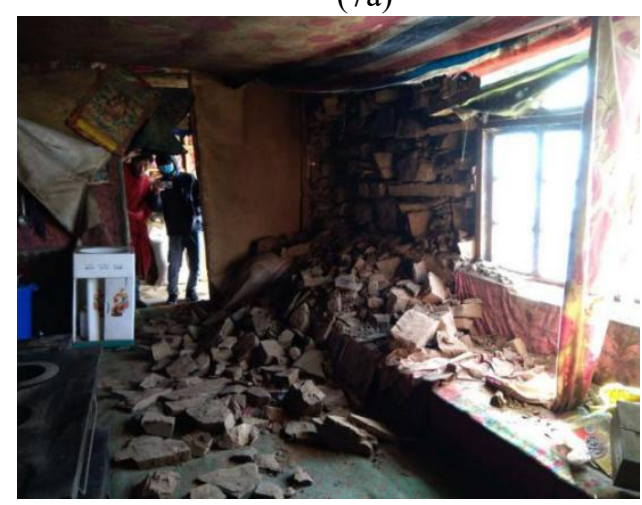

(7b)

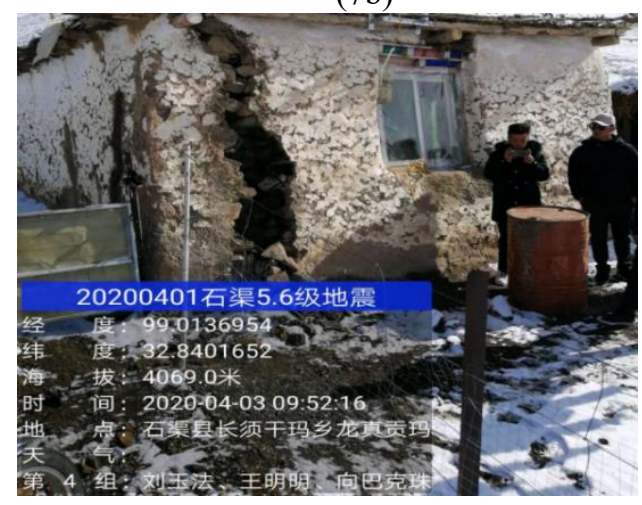

(7c)

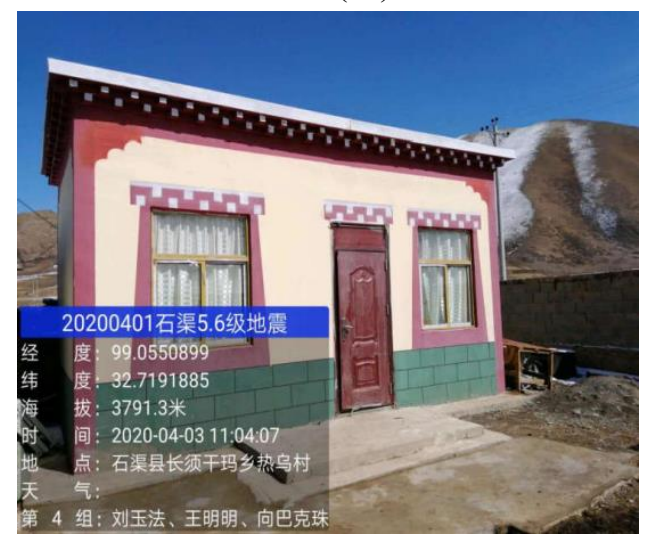

图 7 (a)长须贡马乡尔马底村石木结构房屋墙体局部 垮落;

（b）长须干马乡龙真贡马村石木结构房屋墙体局部 垮塌;

(c)长须干马乡热乌村轻钢结构房屋基本完好 (VII 度 震害照片)

\section{5. 非常态下地震现场考察与应急响应的主}

\section{要措施}

(1) 应急管理部的要求。要切实把思想和行动 统一到习近平总书记重要讲话和中央政治局常委 会会议精神上来, 深刻认识疫情防控的严峻形势, 把人民生命安全和身体健康放在第一位, 切实做到 思想上高度重视、组织上坚强有力、措施上精准管 用, 为坚决打赢疫情防控阻击战提供有力支持 ${ }^{[5]}$ 。

（2）中国地震局的要求。在疫情处置中, 中国 地震局要求要统筹做好疫情防控工作与地震灾害 应急各项准备, 完善疫情防控期间全国大地震应急 处置与重点地区地震活动性分析研判制度, 扎实做 好湖北地区震情研判工作, 立足“抗大震、救大灾”, 落实地震应急响应预案及流程 ${ }^{[5]}$ 。

（3）四川省地震局的要求。四川省地震局组织制 定了《疫情防控期间地震应急工作方案》 $[6]$, 明确规 定了现场工作防控规范和工作纪律要求, 并组织开展 具有针对性的培训，同时指定专人负责地震现场疫情 防控工作，确保疫情防控措施落实。震后应急救援刻 不容缓, 但是在新冠疫情的大背景下, 除了震后救援, 防疫措施也是非常重要的。在应急队员出发前, 四川 
省地震局制定了很多具体的措施, 要求在严格防疫的 同时做好震后救援工作。在做好常态地震应急工作的 基础上，做好应急救援专家队伍的防疫准备工作; 做 好在地震灾区的防疫工作（包含灾民的防疫工作）; 做好当地救援人员的防疫工作; 做任何地震应急救援 措施的决定时都要制定相匹配的防疫措施; 做好当地 灾民在疫情下对发生地震的恐慌心理的疏导工作; 做 好医院、灾民安置区等关键部分的防疫工作。

（4）四川省应急管理厅的要求。四川省应急管 理厅印发了《疫情期间重特大地震应对准备重点工作 方案》 $[1]$ 。要密切关注四川肺炎疫情发展态势, 定时 更新掌握疫情分布范围, 特别是在龙门山、鲜水河、 安宁河一则木河等地震应急处置预案中, 要精确了解 疫情分布的县 (市、区)，掌握每例确诊和疑似病患 所在的乡镇 (街道) 这一信息。一旦省内发生破坏性 地震, 及时共享疫情涉及范围等信息, 指导各部门各 单位提高防范意识。当疫区与灾区重叠时, 对避险安 置、人员转移等容易导致疫情传播的行动, 提出灾区 防疫应对建议或方案，提请相关市（州）、县（区）、 及乡镇做好准备, 避免由于避险安置不当导致疫情扩 散。

《方案》中特别强调要保证应急救援队伍的健康 状况, 对消防救援、森林消防、矿山救护和 49 支省 级应急救援队伍所在单位印发正式通知, 要求每日检 查上报全体人员健康情况, 强化防疫防护物资储备, 坚决杜绝带病工作、带病外出、带病应急等情况。将 全省应急、消防系统和救援队伍的确诊、疑似和隔离 人员信息每日定时通报, 及时指导各单位科学安排轮 替人员, 合理组建现场应急队伍, 确保参与前后方指 挥人员健康, 杜绝任何感染风险。确保发生重特大地 震后随时按照既定预案启动应急响应, 组织救援人员 有序高效开展救援工作。

（5）现场工作人员的疫情防控与健康保障。A、 切实做好疫情防控的物资准备: 应急响应启动时, 第 一时间为工作队伍配备了口罩、防护服及护目镜, 及 一次性手套和消毒用品。B、调整优化出行线路：在 前往震区途中和现场工作期间, 调整优化线路, 采取
有力的防范措施，尽可能避开疫情风险区，严防死守 防疫底线，把接触、感染的风险降到最低。C、对现 场工作人员做出严格的疫情防控要求: 要求对外业人 员在调查过程中必须全程佩戴口罩，及时洗手、做好 衣物消毒, 非特殊情况不得在外用餐, 尽量食用随身 配带的食品; 对在后方集中办公点的人员设置了体温 测量门禁, 要求工作人员间隔 1 米以上办公, 全程佩 戴口罩，每天开展 2 次集中消毒，同时指定专人跟踪 全体队员每日体温变化。D、克服高原反应困难：由 于石渠县平均海拔超过 4000 米, 调查点多数分布在 4200 米至 4600 米的地区, 多数队员不同程度出现了 高原反应症状, 当地县政府、县人民医院给予大力支 持, 送来抗高原反应药物与吸氧设备, 并提供医疗保 障。

\section{6. 结论与建议}

通过对石渠地震的地震活动性、震源机制解、发 震构造、地震烈度分布特征、地震破坏情况的分析, 特别是对在非常态情况下（新冠病毒疫情）地震现场 考察及地震应急响应的不同层面采取的主要措施分 析, 可以得到如下结论:

（1）对地震发震构造认识。从断层活动性、结构与构 造、震源机制解、余震分布等特征综合分析, 认为该 次地震的发震结构为五道樑一长沙贡马断裂。

（2）对地震破坏情况的认识。现场调查及分析表明, 在此次地震中, 土（石）木结构民房破坏相对较重, 轻钢结构民房的破坏较轻, 框架、砖混和轻钢结构公 用房基本无震害。情况表明, 采用相应的抗震措施, 在一定程度上减轻了震害, 有效降低了地震灾害风险。

（3）对非常态下采取的主要措施。要加强对疫情的 研判, 各级组织要制定相应的应急预案, 做好应急防 控物资准备, 调整优化出行线路, 对现场工作人员及 后方集中办公的人员及灾区人员做出严格的疫情防 控要求，采取有效措施克服高原反应。

（4）对非常态下地震应急响应处置效果的认识。由 于采取了有效的防御措施, 各级政府的大力支持, 确 保了现场工作人员、后方工作人员及灾区人员的安全, 
在确保安全的情况下顺利完成了地震现场考察及地 震应急响应任务。

\section{对下一步工作的建议:}

（1）对发震构造深入研究的建议。由于发震构 造初步研究是五道樑 - 长沙贡马断裂, 而且是左旋 走滑断裂。而以前的研究认为这是逆冲断裂, 需要进 一步研究。

（2）对加强基层防震减灾工作的建议。加强对 民房抗震设防能力的提升, 加强对民用住房的抗震设 防的指导; 加强对防震减灾科普知识的宣传、教育。

(3) 对在非常态下地震应急响应预案、相关标 准修订的建议。如果在疫情发生地区再次发生特大、 重大破坏性地震, 已有各级政府、组织的地震应急响 应预案及相关标准需要进一步修订、完善, 不断满足 和适应处置疫情灾害及地震灾害的需要, 避免造成不 同种类灾害损失的叠加, 尽可能减轻综合灾害叠加造 成的损失, 尽最大努力降低和防控综合灾害风险。

\section{致谢}

本研究受国家科技支撑计划项目 （2017YEC1500405）,国家自然基金项目 （DQJB19A0131, DQJB19A0133）的资助, 在此表 示感谢。在开展研究工作中, 得到了四川省地震局 地震现场工作组专家的支持和帮助, 在此深表感 谢。

\section{参考文献}

[1] 四川省应急管理厅印发的《疫情期间重特大地震 应对准备重点工作方案》

[2] 《地震现场工作: 调查规范》（ GB/T 18208.32011 )

[3] 《中国地震烈度表》（GB/T 17742-2008）

[4] 2020 年 4 月 1 日四川石渠 5.6 级地震灾害损失评 估报告
[5] 中国地震局政府网（https://www.cea.gov.cn/）

[6] 四川省地震局印发《疫情防控期间地震应急工作 方案》 